\title{
Angelo Poliziano's De poesi et poetis (BNCF Naz. II.I.99) and the Development of Ancient Dramatic Criticism
}

Giulia Torello-Hill, Griffith University

MANUSCRIPT NAZ. II.I.99 from the Biblioteca Nazionale Centrale in Florence is a collection of a wide array of Greek and Latin classical and late antique sources. Carlo Strozzi (1587-1670) originally attributed it to Marcello Virgilio Adriani (14641521), who took over the chair of Greek and Latin eloquence at the Studio Fiorentino upon the death of Angelo Poliziano in 1494. In 1982, Lucia Cesarini Martinelli cogently argued that the manuscript was in fact the work of Poliziano and his collaborators. ${ }^{1}$ With customary accuracy, she identified all the primary sources quoted or paraphrased in this large collection. Cesarini Martinelli also noted the chronological proximity and thematic correspondences between folios $1 \mathrm{r}-44 \mathrm{v}$ and folios $110 \mathrm{r}-112 \mathrm{r}$ that deal with poetics and poets of antiquity and appropriately titled these sections De poesi et poetis. ${ }^{2}$ In the concluding remarks to her catalog of

Contact Giulia Torello-Hill at Villa I Tatti, Via di Vincigliata 26, Florence 50135, Italy (g.torellohill @griffith.edu.au).

This essay was written during my year of otium as a Hanna Kiel Fellow at Villa I Tatti, the Harvard University Center for Italian Renaissance Studies in 2015-16. I am very grateful to my fellow tattiani Jessie Ann Owens and Elsa Filosa, who have generously shared their expertise with me, to Davide Baldi and Diletta Gamberini, and to the library staff at Villa I Tatti. I also owe thanks to the anonymous referee who made me reconsider various points of this work, to Andrew Turner, and to the editors of this journal, Jane Tylus and Jessica Goethals, for their thorough reading of this essay and their helpful comments. A Discovery Project grant from the Australian Research Council funded my trip to the Bayerische Staatsbibliothek in Munich. Finally, I wish to thank the Biblioteca Nazionale Centrale in Florence (BNCF) for granting me rights to reproduce fols. $27 \mathrm{r}$ and $40 \mathrm{v}$ of Naz. II.I.99. Unless otherwise noted, all translations are my own.

1. Lucia Cesarini Martinelli, "Un ritrovamento polizianesco: Il fascicolo perduto del commento alle Selve di Stazio," Rinascimento 22 (1982): 183-212.

2. Lucia Cesarini Martinelli, “'De poesi et poetis': Uno schedario sconosciuto di Angelo Poliziano,” in Tradizione classica e letteratura umanistica per Alessandro Perosa, ed. Roberto Cardini et al. (Rome, 1985), 455-86. See also the catalog of sources listed in the appendix.

I Tatti Studies in the Italian Renaissance, volume 20, number 1. ๑ 2017 by Villa I Tatti: The Harvard University Center for Italian Renaissance Studies. All rights reserved. 0393-5949/2017/2001-0004\$10.00 
sources, Cesarini Martinelli expressed the hope that others would reexamine this manuscript in the light of Poliziano's literary output and with particular consideration of his Silvae. Yet De poesi et poetis has only received passing mention by the scholarship on Poliziano. ${ }^{3}$

This article revisits this collection of primary sources to discuss the systematic approach of its compilation and its importance as an early testimony of Poliziano's interest in ancient dramatic forms. Poliziano investigates the very essence of poesis, which he traces back to the distant times of the mythical poet-musicians: Linus, Museus, and, above all, Orpheus. This process not only serves to dignify poetry but also establishes a continuum between epic and melic poetry and drama itself. De poesi et poetis is a source of primary importance for understanding both Poliziano's approach to the study of ancient drama and his own contribution to humanist development of dramatic criticism.

\section{THE DATING OF DE POESI ET POETIS}

The BNCF Naz. II.I.99 can be classed as a zibaldone, a miscellaneous collection of texts. Their use is a widespread phenomenon in the early Italian Renaissance. ${ }^{4} \mathrm{Zi}$ baldoni are essentially working notes and were conceived exclusively for personal use as repositories of materials that could be accessed at different stages for pedagogical purposes or for the composition of original works. Their exclusion from public circulation, at least in the initial intention of their authors, does not preclude a systematic approach in their compilation. To the contrary, the materials they contain are carefully selected and often thematically organized.

A large group of zibaldoni, mostly autographs of Poliziano, were collected by his pupil Pietro Crinito, who complemented them occasionally with his own writings. These large repositories were later located and used by Pier Vettori and subsequently acquired by the Bayerische Staatsbibliothek (BSB) in Munich as part of the Vettori fund. ${ }^{5}$ Of particular interest for the scope of this research are folios

3. See, e.g., Angelo Poliziano, Silvae, ed. and trans. Charles Fantazzi (Cambridge, MA, 2004), xvii-xviii; and Francesco Lupi, "Prime ricognizioni sul corpus dei deperdita sofoclei nell'opera di Angelo Poliziano," Acta Classica 56 (2013): 114-35.

4. Mariarosa Cortesi and Silvia Fiaschi note in "Aggregare le parti: Note, letture e documenti nella miscellanea umanistica," Filologia mediolatina 19 (2012): 193-245, 193-95, that there is no clear-cut definition of this kind of manuscript, for which different terms such as miscellanea, zibaldoni, pandette, and anthologies have been used to discriminate among different levels of sophistication. In this context, I will be using the term zibaldone in reference to both Poliziano's working notes and his more elaborated lecture notes. The term miscellanea will only be used to refer to Poliziano's own Miscellaneorum centuriae.

5. These are Latin Manuscripts Clm. 748, 754, 755, 756, and 807 as documented by Carmine Di Pierro, "Zibaldoni autografi di Angelo Poliziano inediti e sconosciuti nella Reale Biblioteca di Monaco," Giornale storico della letteratura italiana 55 (1910): 1-32. 
$203 \mathrm{v}-212 \mathrm{v}$ of Ms Clm. 754, which contain a brief but impressively well-honed introduction to comedy that prefaces a commentary on the first two hundred lines of Terence's Andria. The introduction and the commentary were written as part of a course on Terence that Poliziano delivered at the Studio Fiorentino, most likely in $1484-85{ }^{6}$

Poliziano's interest in ancient drama also extended to Greek theater, as documented by the BSB Ms Cgm. 812 (fols. 90v-106v), which contains the scholia to Aristophanes's Acharnians and Knights. Finally, the large Parisian zibaldone, Bibliothèque nationale de France gr. 3069, is once again an autograph of Poliziano and preserves select scholia to several plays by Aristophanes, to Aeschylus's Agamemnon and Eumenides, and to Euripides's Hippolytus (fols. 12r-49r).

Like other zibaldoni, the Florentine manuscript contains numerous notabilia in red ink, and passages of particular interest are singled out by semeiosai, manicula, and vertical lines. In quoting ancient sources, Poliziano always draws on the original Greek text even when a particular work is widely available in Latin translation. For instance, he quotes passages from Diogenes Laertius's Lives of Eminent Philosophers (fols. 4r-8r) entirely in the original Greek and disregards completely the translation of Ambrogio Traversari. ${ }^{7}$

As for the dating of the manuscript, an autograph colophon that follows the excerpts from Pausanias's Description of Greece (fol. 40v; fig. 1) reads as follows:

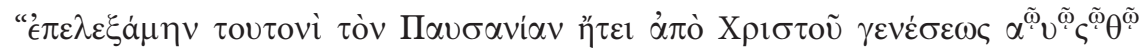

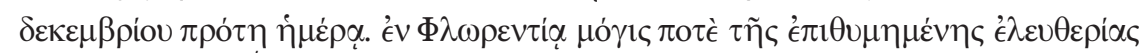

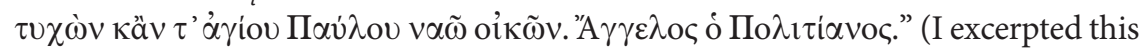
Pausanias in the year 14 ? 9 from the birth of Christ, on the first day of December in Florence, having found a much longed-for freedom and while I was living in the

6. The Andria Terentii was edited by Rosetta Lattanzi Roselli, La commedia antica e l'Andria di Terenzio (Florence, 1973). For a convincing discussion of the dating of the course on Terence, see xi-xii. The introduction to comedy that served as a preface to a commentary on Terence's Andria takes up fols. 203v-209r of BSB Clm. 754. It treats the generic features of comedy, the periodization of comedy, its origin, the parts of comedy, the development of tragedy, comic stock characters on the basis of the classification provided in Pollux, Onomastikon IV.143-54, music and comedy, and the role of the chorus in classical comedy. Poliziano drew on the Latin late antique works on comedy of Evanthius and Donatus, as well as a broad range of Greek sources, including Aristotle, Pollux, and the anonymous Byzantine tract On Comedy. For an overview of the courses delivered by Poliziano at the Studio Fiorentino, see Lucia Cesarini Martinelli, "Poliziano professore allo studio Fiorentino," in La Toscana al tempo di Lorenzo il Magnifico: Politica, economia, cultura e arte; Convegno internazionale di studi: Firenze, Pisa, Siena 5-8 novembre 1992 (Pisa, 1996), 2:463-81.

7. On Traversari's translation of Diogenes's Lives and more generally on its popularity throughout the Renaissance, see Ilario Tolomio, "Editions of Diogenes Laertius in the Fifteenth to Seventeenth Centuries," in Models of the History of Philosophy: From Its Origins in the Renaissance to the "Historia philosophica," ed. C. W. T. Blackwell and Philip Weller (Dordrecht, 2011), 1:154-60. 


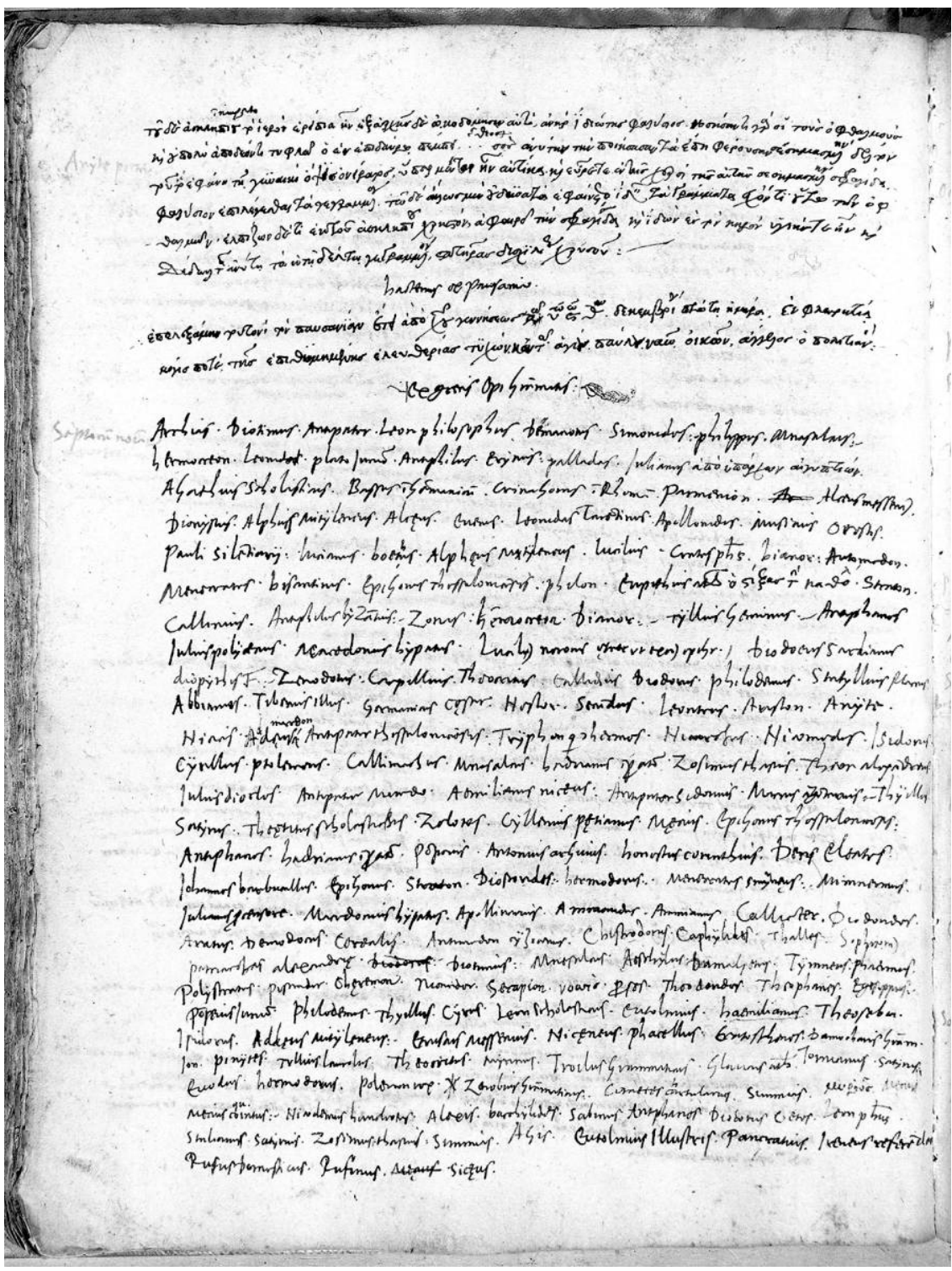

Figure 1. Colophon autograph of Poliziano. Ms Naz. II.I.99 (ca. 1479), folio 40v, Biblioteca Nazionale Centrale, Florence. With the permission of the Ministero dei beni e delle attività culturali e del turismo/Biblioteca Nazionale Centrale, Firenze; no further reproductions permitted. Color version available as an online enhancement. 
small Church of San Paolo. Angelo Poliziano.) The year of the compilation is uncertain since $\varsigma$ (stigma) is used in ancient Greek and Byzantine numerical systems for units-it corresponds to the number 6-and not for tens. Cesarini Martinelli was forced to admit Poliziano's error. Among the three possible emendations that the lifespan of Poliziano allows, 1469, 1479, and 1489, she opted for the middle date. Her main argument for preferring 1479 over the earlier or later date was Poliziano's extensive use of these materials for the composition of his commentary to Statius's Sylvae, which was written in $1480-81 .{ }^{8}$ The colophon provides us with another chronological pointer that corroborates the dating of 1479. Poliziano states that he compiled the first forty folios of the zibaldone during a period of quiet study at the church of San Paolo. This church, which is better known as the Church of San Paolino since it was built in the fourth century as a smaller church, ${ }^{9}$ is located a short distance from both the church of Santa Maria Novella and Florence's Cathedral of Santa Maria del Fiore. Documentary evidence confirms that Poliziano was the prior of San Paolino between 1477 and 1486, when he was appointed canon of Santa Maria del Fiore. ${ }^{10}$ Since he specifically states that he was dwelling (oik $\tilde{\omega} v$ ) in the church, the compilation of at least the first forty folios of De poesi et poetis can be firmly set within this chronological span and most likely in 1479 if the final digit of the date is correct.

\section{POETRY VERSUS PHILOSOPHY}

Folios $1 \mathrm{r}-44 \mathrm{v}$ of the zibaldone collect a wide range of excerpted sources, including the Chronicon of Eusebius-St. Jerome, a synopsis of book 14 of Boccaccio's Genealogy of the Pagan Gods (Genealogie deorum gentilium), Diogenes Laertius's Lives of Eminent Philosophers (4r-8r), a large body of quotations from Plutarch's Moralia (8r-26r), and lemmas from the Byzantine lexicon of the Suda. Excerpts from Diogenes Laertius and Plutarch are of particular interest, as they contain repeated references to the ancient quarrel between poetry and philosophy. Poliziano quotes

8. Cesarini Martinelli, "De poesi et poetis," 474. Discussed in detail in Lucia Cesarini Martinelli, "In margine al commento di Angelo Poliziano alle Selve di Stazio," Interpres 1 (1978): 96-145.

9. On the church of San Paolino, see Ettore Puccioni, La chiesa di San Paolo Apostolo a Firenze (Florence, 1976); and Bernardo di Santa Teresa, La chiesa di San Paolo Apostolo a Firenze: Storia, illustrazioni e documenti (Florence, 1976). The church was rebuilt almost entirely in the seventeenth century. It underwent complete restoration in the 1970s, as detailed in Lia Pescatori, La chiesa di San Paolo Apostolo a Firenze detta di San Paolino: Restauri recenti (Florence, 2008).

10. Gian Battista Picotti, "Tra il poeta ed il lauro," Giornale storico della letteratura italiana 65 (1915): 297-303; on Poliziano's involvement with San Paolino, see Alexander Röstel, "'Una Pieta chon molte figure': Sandro Botticelli's Altarpiece for the Florentine Church of S. Paolino,” Burlington Magazine 157 (2015): 521-29. I thank Alexander very much for discussing this matter with me. 
passages that discuss the ban of dramatic performances. Solon's forbidding Thespis from staging tragic performances, as referenced in Diogenes Laertius, Lives of Eminent Philosophers 1.59, appears at folio 4v accompanied by manicula. Epicurean and Stoic criticism of poetry are recorded in the excerpts from Plutarch's Moralia. ${ }^{11}$ Plutarch maintains a polemical stance against these philosophical doctrines. In the treatise It Is Not Possible to Live Happily Following Epicurus, he contends that Epicurean theories make it impossible to gain the pleasure that should be the ultimate goal of Epicurean teachings. In section 1093b, which Poliziano transcribes in folio 8r, Plutarch reflects on the Epicurean stance against poetry, and he concedes that the emotional response elicited by tragedy could be potentially devastating. He illustrates this by quoting the lines of Oedipus Rex (1169-70) in which Oedipus solicits the unveiling of the truth and meets his doom. Plutarch suggests that even greater pleasure could be gained in hearing stories, such as the historical accounts of Herodotus and Xenophon, which are also affectively safe. As for Plutarch's polemical stance against Stoicism, Poliziano selects a brief passage from the Summary of The Stoics Talk More Paradoxically than the Poets. In this quote (1058c), it is said that poetic fictions may lack plausibility, but unlike Stoic paradoxes, they are coherent.

Poliziano also reports Plato's censorious attitude toward performing arts, as described in Plutarch's Glory of the Athenians 348b (fol. 9r). Plato's accusation of the falsehood of myth is highlighted through manicula. Poliziano also transcribes Plato's prohibition against writing comedy, which he depicts as an undignified form of art, and his intimation that tragedy is essentially deceptive (348c).

The rejection of poetry as a vehicle of lies (mendacia) forms a large part of Poliziano's summary of the fourteenth book of Boccaccio's The Genealogy of the Pagan Gods. ${ }^{12}$ The inclusion of these passages is notable for two reasons. First of all, Boccaccio is the only modern author that makes his way into this collection of classical and late antique sources. Second, this is the only case in which Poliziano relinquishes verbatim quotations for a well-honed synopsis of his source. Elsewhere in the manuscript, Poliziano provides short summaries in Latin of sections of works alongside quotations. But his summary of Boccaccio's book 14 is a far more sophisticated intervention. Poliziano includes ancient sources that detail the detrimental effects of dramatic arts over personal morality and the institutionalized cen-

11. For a discussion of Plutarch's conspicuous references to Epicurean philosophy and his antiEpicurean sentiments, see Eleni Kechagia-Ovseiko, "Plutarch and Epicureanism," in A Companion to Plutarch, ed. Mark Beck (Chichester, 2014), 104-20. For his anti-Stoic works, see Jan Opsomer, "Plutarch and the Stoics," in Beck, Companion to Plutarch, 88-103.

12. De poesi et poetis, fols. $2 \mathrm{v}-4 \mathrm{r}$. Poliziano's synopsis of the fourteenth book of the Genealogy is fully transcribed in Cesarini Martinelli, "De poesi et poetis," 458-61. 
sorship of the performing arts. The paraphrase of Cicero's On the Republic 4.10 testifies how in ancient times those who engaged in theatrical practice were removed from their tribes (Boccaccio, Genealogy 14.14, fol. 3v). Boethius's reference to dramatic plays as "theatrical courtesans" (scenicas meretriculas) who further weaken the precariously healthy condition of Philosophy is also included in Poliziano's selective summary of chapters $7-22 .{ }^{13}$

Poliziano paraphrases the passage of Boccaccio's Genealogy that addresses the accusations leveled against poetry. Boccaccio argues that the greatest poets lived a frugal and contemplative life, and their writing has been a continuous source of inspiration for Christian authors such as Fulgentius, Saint Augustine, and Saint Paul. Poliziano also includes the remarks about the familiaritas that both ancient and Christian authors enjoyed with rulers and patrons. Once again, Euripides, Ennius, and Vergil feature alongside Dante and Petrarch. ${ }^{14}$ The obscurity (obscuritas) of their poetry is another correspondence that Boccaccio draws between ancient poets and Christian authors. This adheres to the principle that theological truth is wrapped up with the veil of poetry and often couched in the language of allegory (allegoria). ${ }^{15}$

Christian poets' stylistic imitation (imitatio) of ancient poetry is a further argument against the charges of immorality leveled at ancient authors. Poliziano paraphrases Boccaccio's examples of poetic imitation, stating that Saint Jerome's prologue to his Hebrew Questions on Genesis is “entirely Terentian” (totum Terentianum) and that Saint Paul resorted to a line from Menander in his Letters to the Athenians.

The defense of poetry's value is one of the core topics of book 14 of the Genealogy, one that Boccaccio revisits in the second redaction of his work. ${ }^{16}$ Boccaccio upholds the medieval tenet of the poet as a theologian and the carrier of divine truth. ${ }^{17}$ This idea, which rests on an imprecise interpretation of Aristotle's Meta-

13. Boethius, De consolatione I.1.28.

14. Boccaccio, Genealogy 14.11, fol. 3r.

15. It paraphrases Genealogy 14.13, fol. 3v. Boccaccio uses the periphrasis artificio et velamento poetico.

16. The second redaction began to circulate around the early to mid-1370s and incorporated the suggestions of Neapolitan intellectuals such as Pietro Piccolo da Monteforte. See Jon Solomon, "Gods, Greeks and Poetry," in Boccaccio: A Critical Guide to the Complete Works, ed. Victoria Kirkham et al. (Chicago, 2013), 235-44, 237.

17. See Giorgio Ronconi, Le origini delle dispute umanistiche sulla poesia (Rome, 1976); Michael Papio, "Boccaccio: Mythographer, Philosopher, Theologian," in Boccaccio in America: Proceedings of the 2010 International Boccaccio Conference at the University of Massachusetts Amherst, ed. Michael Papio and Elsa Filosa (Ravenna, 2012), 123-42, 128-29, and "Boccaccio between Mussato and the Neoplatonists," in Boccaccio, 1313-2013, ed. Francesco Ciabattoni, Elsa Filosa, and Kristina Olson (Ravenna, 2015), 275-86, esp. 279; Solomon, “Gods, Greeks and Poetry," 237. For the interpretation of pagan 
physics, was revived by Albertino Mussato and widely spread among Paduan humanists, including Petrarch. In chapters 8 and 13 of the Genealogy, ancient poetry is also further exonerated from charges of immorality. Since it was written before the advent of Christianity, it cannot contain theological truth. ${ }^{18}$ In the Genealogy 14.10, Boccaccio finds the compatibility between poetry and theology in the poetry of Dante, as he had exemplified in the early Trattatello in laude di Dante. In his rehabilitation of Dante's poetry, Boccaccio not only presents him as the poeta theologus but also depicts him as a novel Vergil. ${ }^{19}$ In so doing, he successfully establishes a connection between Dante's vernacular works and classical poetry. In his synthesis of Boccaccio's Genealogy 14.10, Poliziano steers away from the paradigm of the poeta theologus. He briefly summarizes chapter 10, stating simply that Boccaccio argues against those who deny that poets veiled the deep meaning of their fabulae in allegory and invokes the authority of Vergil, Dante, and Petrarch. The fact that Poliziano deliberately eschews considerations over the analogy between poetry and theology does not preclude him from believing poetic divine inspiration. Significantly, Poliziano opens his synopsis of book 14 of the Genealogy with a verbatim quote from the opening of chapter 7 . In this passage Boccaccio defines poetry as "a fervor of exquisite invention and of expression, in speech or in writing, of what has been discovered" (Gen. 14.7). This quote is immediately followed by another one, this time from Cicero, which echoes the Platonic concept of divine frenzy: a poet "is stirred by the force of his mind and is inspired, as it were, by a sort of heaven-sent afflatus." 20

\section{ORPHEUS AS THE EMBODIMENT OF POETRY}

A pervasive theme of the excerpts collected in De poesi et poetis is that of the characterization of mythical poets. In the mythical past, poet-musicians such as Musaeus, Linus, and Orpheus were classed among the seven savants. Poetry carried divine truth insofar as it was the language of oracles. Poetry and philosophy

poetry as a theologia poetica particularly in reference to the reception of Vergilian poetry in the Renaissance, see Craig Kallendorf, "From Virgil to Vida: The Poeta Theologus in Italian Renaissance Commentary," Journal of the History of Ideas 56 (1995): 41-62. A wider overview is provided in Charles Trinkaus, In Our Image and Likeness: Humanity and Divinity in Italian Humanist Thought (Chicago, 1970).

18. See, esp., Boccaccio, Genealogy 14.8 and 13, which are omitted altogether in Poliziano's synopsis. See Papio, "Boccaccio: Mythographer," and "Boccaccio between Mussato and the Neoplatonists," 279.

19. In the abridged version of the Trattatello known as Compendio (1360), Boccaccio curtails this statement and defines poetry only as "similar" to theology ("simigliante di quella"; 2.91). See Elsa Filosa, "To Praise Dante, to Please Petrarch," in Kirkham et al., Boccaccio: A Critical Guide, 213-20, 218.

20. Cicero, Pro Archia 18, quoted in Boccaccio, Genealogy 14.7; Cicero, Pro Archia, trans. Arthur H. Allcroft and Francis G. Plaistowe (London, 1892), 8. Poliziano treats more extensively the concept of divine frenzy in his Rusticus. See Fantazzi, Sylvae, xvii. 
were closely intertwined, as stated in a passage that Poliziano quotes from Strabo's Geography, 1.2.3, folio 43r:

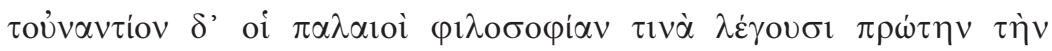

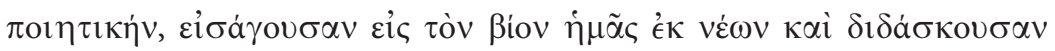

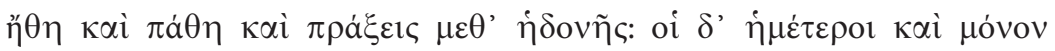

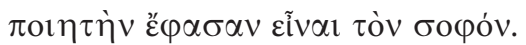

[The ancients assert, on the contrary, that poetry is a kind of elementary philosophy, which, taking us in our very boyhood, introduces us to the art of life and instructs us, with pleasure to ourselves, in character, emotions, and actions. And our School goes still further and contends that the wise man alone is a poet. $]^{21}$

Orpheus plays a fundamental role in fifteenth-century thought; he is the source of all esoteric religion, and his doctrines are believed to have influenced the Pythagoreans and, indirectly, Plato. Renaissance intellectuals such as Marsilio Ficino and Giovanni Pico della Mirandola viewed Orphic Hymns as a form of pre-Christian revelation, veiled by allegorical myths. The identification of Orpheus as the first theologian allows Ficinian philosophy to reconcile Platonism with Christianity and emancipate ancient poets from the stigma of immorality. ${ }^{22}$

In De poesi et poetis, however, Poliziano focuses mainly on the ancient narratives of the myth of Orpheus. ${ }^{23}$ His tragic death caused by women is referenced twice in the manuscript: in the accounts of Diogenes Laertius and Pausanias. ${ }^{24} \mathrm{Di}$ ogenes Laertius (1.5) presents two different versions of Orpheus's death: in one version his death was perpetrated by women, and in the other it occurred as the result of divine retribution. Pausanias's account of the myth of Orpheus is far more extensive and includes details of his descent to the underworld to retrieve Eurydice (9.30.4, 9.30.6), the two contrasting versions of his demise (9.30.5), the place of his death (9.30.7), and the place of his burial, which according to a different version of the myth is in the city of Libethra in Thrace (9.30.9). All these references to Orpheus most likely were fundamental background materials for Poliziano's characterization of Orpheus in both the Fabula de Orfeo and his Sylvae.

21. Strabo, Geography, bks. 1 and 2, trans. Horace Leonard Jones (Cambridge, MA, 1969), 55.

22. D. P. Walker, "Orpheus the Theologian and Renaissance Platonists," Iournal of the Warburg and Courtauld Institutes 16 (1953): 100-120. See Michael J. B. Allen, Synoptic Art: Marsilio Ficino on the History of Platonic Interpretation (Florence, 1998), esp. 93-123.

23. For an insightful discussion of Orpheus's prominence among Renaissance intellectual circles and the perception of him as a "theological writer," see Walker, "Orpheus the Theologian."

24. Diogenes Laertius, Lives of Eminent Philosophers 1.5 (fol. 4v); and Pausanias, Description of Greece 9.30.4-11 (fol. 28v). 
Orpheus is the embodiment of poesis, a term that encompasses verse and music. This is very clearly emphasized by Poliziano when he quotes in extenso a passage from the Pseudo-Plutarchean On Music 1132b-f that details the birth of music in

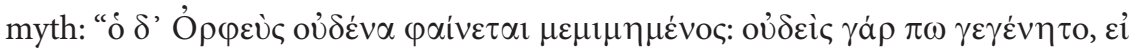

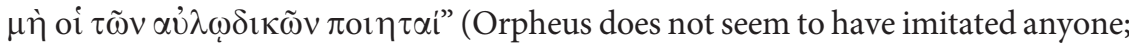
indeed before him no one was a musician, except the aulodic poets; Plutarch, On Music 1132f, fol. 11v). The verbatim quotation ends with this appraisal of Orpheus before Poliziano switches once again to Latin to provide a summary of subsequent sections of On Music.

\section{POETRY AND MUSIC}

Musical accompaniment is the natural complement to any poetic verse. Arguably, both ancient and humanist poets regarded poetry as music. ${ }^{25}$ In his collection of sources, Poliziano includes extensive excerpts from the Pseudo-Plutarchean dialogue On Music. At least two manuscripts of this text were part of the large collection of the Medici library, Florence Biblioteca Medicea Laurenziana, Plut. 58, 29 (q) and the current Paris Bibliothèque nationale de France gr. 2451 (s) (former Mediceus Regius 2717). Before its inclusion in the Aldine edition of Moralia (1509), On Music was published individually in a Latin translation in 1507. The author of this translation, Carlo Valgulio, had developed a bond of friendship and mutual respect with Medicean circles. ${ }^{26}$

Poliziano quotes almost entirely sections $1132 \mathrm{~b}-\mathrm{f}$ that detail the "birth" of music through a brief account of mythical poets from the past, from Linus, Anthes of Boeotia, and Pierus of Pieria, to focus on Terpander, who is credited with being the first poet to set musical accompaniment to his nomic compositions in hexameter. He also records the musical developments of fifth-century Athens, when musical accompaniment became more sophisticated and more prominent than poetic composition itself $(1141 \mathrm{~b}-\mathrm{d}) .{ }^{27}$ This passage, along with the account of Athenaeus, is the only systematic treatment of the "musical revolution" that would otherwise be known only through the humorous attacks of Athenian fifth-century

25. Nino Pirrotta, Li due Orfei: Da Poliziano a Monteverdi (Turin, 1969), 22.

26. On Valgulio's translation of Plutarch's On Music, see Angelo Meriani, "Carlo Valgulio e il testo del De musica," Quaderni urbinati di cultura classica 99 (2011): 229-58. A letter addressed by Valgulio to Poliziano in 1485 is transcribed by Ida Maïer, Ange Politien: La formation d'un poète humaniste, 1469-1480 (Geneva, 1965), 391-93.

27. Andrew Barker, Greek Musical Writings, vol. 1: The Musician and His Art (Cambridge, 1984), 99ff. 
comic playwrights. ${ }^{28}$ Musical innovations were not simply introduced in the context of comic and tragic plays but extended to other forms of musical composition such as solo pieces with the accompaniment of a kithara (kitharodic nomoi) and choral compositions (dithyrambs). In On Music, the brief introduction to musical changes is exemplified by the citation of a passage from comic playwright Pherecrates, in which Poesis is personified and laments having been harassed by a string of abusive new musicians. ${ }^{29}$ Poliziano does not quote the Pherecretean lines, but the introductory statement on musical innovations and the short synopsis of the play is highlighted by a marginal vertical line.

Poliziano's interest in ancient music was not limited to De poesi et poetis. Another zibaldone, also uncovered by Cesarini Martinelli, Munich BSB Ms Clm. 798, contains excerpts from Sextus Empiricus's Against the Musicians, a work that was virtually unknown to humanists. ${ }^{30}$ The interest in Sextus Empiricus lies in the interrelation between philosophy and music, which both aim to regulate human passions and are fundamental educational tools. With the carefully selected excerpts from the Pseudo-Plutarchean On Music, however, Poliziano's aim is to trace a succinct history of ancient music that culminates with the musical innovations introduced into the dramatic arts.

\section{NUMERUS AND VERSUS: DEFINING THE FEATURES OF POETRY}

Folios 109r-12r of BNCF Naz. II.I.99 contain another set of excerpts from various sources, which are mostly written by the hand of Poliziano. This section of the

28. Aristophanes, Clouds 635-67, 961-72; Knights 985-95; Wasps 1208-50; Women at the Thesmophoria 95-174; Birds 903-57, 1373-1409; Frogs 202-68, 1296-1318. See Barker, Greek Musical Writings, 99-116. A polemical stance against musical innovations is likely to be a theme of Eupolis's Demes. An Apulian bell-krater that illustrates an altercation between the comic hero Pyronides and the musician Phrynis has long been associated with a lost scene from this play. See Oliver Taplin, Comic Angels: And Other Approaches to Greek Drama through Vase-Paintings (Oxford, 1993). Athenaeus's account of the musical innovations is at Deipnosophistae 14.616e-617f. Pauline A. LeVen, "New Music and Its Myths: Athenaeus' Reading of the Aulos Revolution (Deipnosophistae 14.616e-617f)," Lournal of Hellenic Studies 130 (2010): 35-47, contends that Athenaeus's view does not reflect the sentiments of fifthcentury Athens but represents an elaboration of Aristotelian doctrines.

29. On this passage, see Gregory Dobrov and Eduardo Urios-Aparisi, “The Maculate Music: Gender, Genre, and the Chiron of Pherecrates," in Beyond Aristophanes: Transition and Diversity in Greek Comedy, ed. Gregory Dobrov (Atlanta, 1995), 139-74; Barker, Greek Musical Writings, 236-38.

30. Lucia Cesarini Martinelli, "Sesto empirico e una dispersa enciclopedia delle arti e delle scienze di Angelo Poliziano," Rinascimento 20 (1980): 327-58. On the classical sources on music that can be traced in Poliziano's work, see Fiorella Brancacci, "Le fonti musicali classiche nell'opera di Poliziano," Interpres 12 (1992): 135-49. A separate zibaldone, BSB 748, fols. 112r-116v, which is mostly written by Crinito, preserves Saint Augustine's On Music by the hand of Poliziano as attested by the colophon at fol. $117 \mathrm{v}$. 
zibaldone cannot be firmly dated but was probably written shortly after folios 1r$44 \mathrm{v}^{31}$

While the choice of secondary sources is quite wide-ranging, the core of this miscellaneous collection is arguably the discussion of verse and prose and the similarities between poetry and rhetoric, as exemplified by Cicero in the Orator. Cicero discusses the notion of numerus (the Greek rhythmos), commonly considered to be the distinguishing feature of verse and prose. Greek and Latin ancient verse was based on a combination of quantitative syllables that gave birth to a wide variety of meters. ${ }^{32}$ In the quoted passages from De Oratore 66-67, Cicero remarks that poets used to set themselves apart from orators on the basis of rhythm (numerus) and verse (versus), although rhythm is no longer a distinguishing feature since it has become common in orators. Poliziano highlights the importance of this short passage, which follows three short quotations on Greek and Latin poets, with semeiosai and manicula. The comparison between poetry and oratory extends to the quotation of Tacitus's Dialogue on Oratory 12-13 (fol. 111v). In this passage, Tacitus views poetry as the original and purest form of human utterance, the language of oracle. Unlike oratory, it is free from any constraint insofar as it is not produced for material or personal gain.

Poliziano includes Cicero's further consideration on the distinguishing features of prose and poetry. In De Oratore 174 (fol. 110r), Cicero contends that the difference between prose and verse is not clear-cut. For instance, Isocrates uses poetic meters in his oratorical speeches in order to elicit pleasure (voluptas) in his audiences. ${ }^{33}$ On the other hand, as he remarks at De Oratore 183-84 (fol. 110v), once one takes away the musical accompaniment, Greek lyric poems are similar to bare prose (nuda oratio). This sometimes happens in Latin poetry and at least once in tragedy with the Thyestes of Ennius.

\section{THE FEATURES OF DRAMATIC GENRES}

Defining the features of poetry inevitably leads Poliziano to a categorization of poetic genres and, in particular, of dramatic genres. His interest in generic features is apparent in his references at folios $2 \mathrm{v}-3 \mathrm{r}$ to Boccaccio's definition of fabulae as it appears in the The Genealogy of the Pagan Gods 14.9 (fols. 2v-3r). I quote the text in extenso:

31. Compare Cesarini Martinelli, "Un ritrovamento polizianesco," 189, who reached this conclusion on the grounds of codicological and paleographical analysis.

32. Timothy J. Moore, Music in Roman Comedy (Cambridge, 2014).

33. See also Cicero, De Oratore 191, which is quoted by Poliziano at fol. 110v. Cicero infers that iambic meters are particularly suited to oratory, as they resemble everyday speech, while the dactyl is more appropriate for loftier styles. 
"fabula est exemplaris seu demonstrativa sub figmento locutio, cuius amoto cortice, patet intentio fabulantis." ${ }^{34}$ Ibi quattuor enumerat fabularum genera: quae verisimiles non sunt, ut Aesopicae; quae partim verisimiles sunt, partim contra, quales Ovidii sunt fabellae; quae historiae sunt similes, ut heroum gesta, ut comoediae; quarta est speties earum, quae nihil omnino veritatis nec intus nec in cute habeant, quales sunt anicularum fabellae.

["A narrative is a form of discourse under the veil of fiction that exemplifies or proves a point; once the superficial layer is removed, the intention of the narrator is apparent." Here, he [i.e., Boccaccio] lists four narrative genres: those that lack verisimilitude, such as Aesop's fables; those which are partly verisimilar and partly not, like Ovid's tales; those which are similar to historical accounts, like heroic deeds and comic plays; and the fourth type of these narratives are those in which no truth whatsoever inheres, neither on their surface nor in their deeper meaning, like old wives' tales.]

An element of great interest in Poliziano's paraphrase of Boccaccio's Genealogy is the categorization of the different subgenres of the fabula: in particular, the definition of comedy as being very similar to history and thus as being by definition very close to truth itself. ${ }^{35}$

De poesi et poetis clearly reflects Poliziano's in-depth analysis of classical drama, whose features will be discussed extensively in Andria Terentii. This approach is evident right at the outset of the zibaldone, which contains excerpts from the Chronicon of Eusebius-Saint Jerome. ${ }^{36}$ Poliziano eschews the historical details that abound in the Chronicon to annotate only biographical details of classical poets. This careful selection results in a short but enthralling history of Roman literature during the Republican and imperial eras, from Naevius to Claudian dramatists. Particularly notable are the references to Roman dramatists who are virtually unknown, such as the comic playwright Turpilius or the mimograph Philistio, who are accurately recorded in the manuscript. ${ }^{37}$ Poliziano aims at gathering a wide-

34. Isidore of Seville, Etymologies 1.40.6. For Boccaccio's reliance on materials drawn from late antique sources such as Isidore, Servius, Lactantius, Macrobius, Fulgentius, and Augustine, see Giovanni Boccaccio, Genealogy of the Pagan Gods, ed. and trans. Jon Solomon (Cambridge, MA, 2011), xiii-xvii.

35. In a passage that Poliziano does not include in his synopsis, Boccaccio specifies the events of comedy in this way: "since they are common, if they have not taken place, they could have happened or they might happen" (Gen. 15.9). His categorization of fabulae does not encompass tragedy or any dramatic form other than comedy.

36. BCNF II.I.99 fols. 1r-2v.

37. According to Pietro Crinito, Turpilius was a contemporary of Terence. For the scholarly disagreement over Turpilius's chronology, see Evangelos Karakis, Terence and the Lanquage of Roman Comedy (Cambridge, 2005), 150. 
ranging array of sources by the inclusion of dramatists whose works survive only in fragments.

The entries from the Byzantine lexicon of the Suda, which takes up folios 26r$28 \mathrm{v}$ and includes a selection of entries of ancient poets from Acas to Archippus, are once again representative of Poliziano's systematic approach. ${ }^{38}$ The lemmas are autographs of Poliziano, and the shorter entries are usually written in Latin. ${ }^{39}$ Longer entries are sometimes a literal translation of the Greek original, whereas other times Latin and Greek alternate. As happens throughout the zibaldone, there are frequent notabilia written in the margins in red ink. The distinctive feature of the marginal notabilia of the excerpts from the Suda is that they identify the dramatic genre of the listed authors through abbreviations for tragedy (tr.), comedy (co.), dithyramb (dyth.), and lyric (lyr.; fig. 2). While the majority of authors are tragedians and comedians, the inclusion of some exponents of other genres is notable. In listing Archilochus (fol. 28v), Poliziano skips the first two sentences from the Suda and starts from the point where the iambographer is credited for his use of obscene (aischroepes) and abusive language (kakoremon). ${ }^{40}$ The musicians Amphion and Antigenides and lyric poets Alcman and Arion are also included in this selection. Alcman is credited by the Suda as the inventor of erotic poetry and for his metrical innovations, Arion of Methymna with inventing the "tragic style" and with introducing choruses and dithyrambs. ${ }^{41}$ The comic playwright Anaxandrides is also remembered as "the first to introduce love-affairs and rapes of girls," two themes that are certainly crucial to the plots of New Comedy. ${ }^{42}$

Poliziano's interest in the generic features of ancient drama is also testified by his inclusion in De poesi et poetis of the Summary of a Comparison between Aristophanes and Menander (Comparationis Aristophani et Menandri compendium), attributed to Plutarch. This abridged version of a more extensive treatise is the only ancient work that Poliziano has transcribed entirely in the zibaldone. In the compendium, the "coarseness" ( $\tau$ ò $\varphi \rho \rho \tau 1 \kappa o ́ v)$ of Aristophanic plays is contrasted with Menander's polished and "well blended" style. The periodization of Greek

38. Ada Adler, Suidae Lexicon (Munich, 2001), 76-376 passim. Poliziano transcribes excerpts from the Suda also in zibaldoni Florence BNCF Ms Magl. VIII 1420 and Munich BSB Ms Clm. 798. Manuscript BSB Cgm. 182 (fols. 1r-58r) contains a compendium of the whole lexicon and is dated 1472. See Luigi Silvano, "New Readings and Glosses to Suidas from an Autograph of Angelo Poliziano," Erytheia 30 (2009): 215-29, 218-19 n. 12 with full bibliography.

39. For example, "Acas poeta tragicus" at fol. 28r (Suda 808).

40. Ralph M. Rosen, Old Comedy and the Iambographic Tradition (Atlanta, 1983).

41. Suda 3886 , fol. $17 \mathrm{v}$.

42. Suda 1982, fol. 26v. 


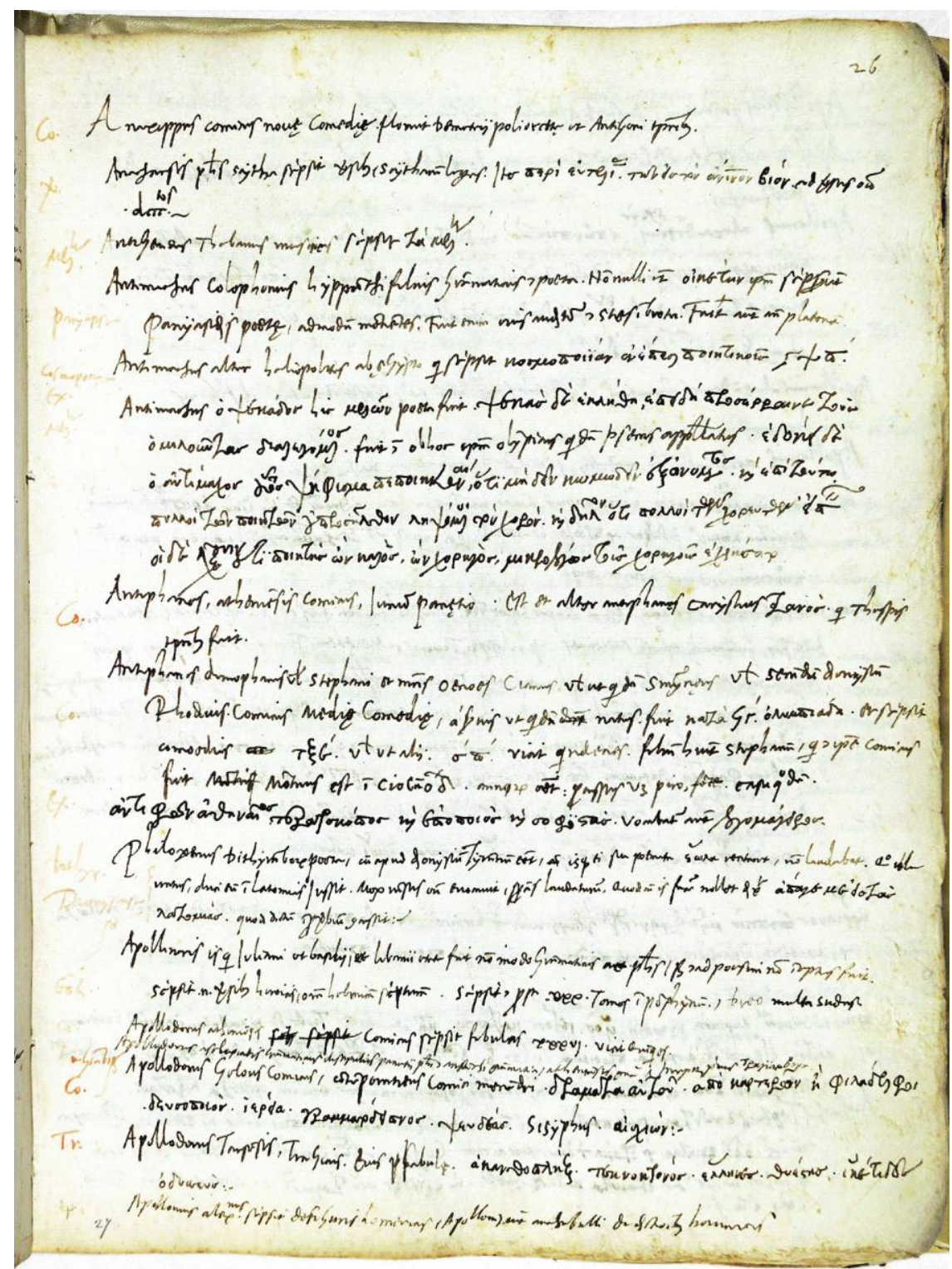

Figure 2. Suidae Lexicon from Anaxippus (1991) to Apollodorus (3406) passim. Ms Naz. II.I.99 (ca. 1479), folio [27r], Biblioteca Nazionale Centrale, Florence. With the permission of the Ministero dei beni e delle attività culturali e del turismo/Biblioteca Nazionale Centrale, Firenze; no further reproductions permitted. 
comedy into Old, Middle, and New will form part of Poliziano's introduction in Andria Terentii. ${ }^{43}$

\section{CONTEXTUALIZING DE POESI ET POETIS}

De poesi et poetis illustrates Poliziano's early interest in ancient drama and reflects the inclusion of Latin dramatic texts in the Florentine school curriculum in the last quarter of the fifteenth century. It is at this time that the revival of Latin in school settings goes well beyond "the technicalities of language." 44 Classical drama, among other secular Latin texts, offered very suitable materials to train pupils in rhetoric. In a city whose wealth largely depended on commercial and financial enterprises, the ability to communicate clearly and effectively was paramount. Thus, from the early fifteenth century pupils in Florentine schools were trained in rhetorical skills through drama. Such rhetorical exercises were based initially on religious drama (sacre rappresentazioni) that were often written ad hoc by the teachers themselves. ${ }^{45}$ Performances of classical plays entered school settings only in the last quarter of the century. The staging of Terence's Andria by the pupils of Giorgio Antonio Vespucci in 1476 inaugurates the revival of classical drama not only in Florence but in Italy. The play was staged at school as well as in the Medici palace and Palazzo Vecchio. Much less is known about the performances of other Latin plays staged by the pupils of Pietro Domizi in the church of Ognissanti and the Medici palace in 147879 and the performance of a play of Plautus by the pupils of Luca Bernardi da San Gimignano. ${ }^{46}$

43. Lattanzi Roselli, La commedia antica, 8-9.

44. Robert Black, Education and Society in Florentine Tuscany: Teachers, Pupils and Schools, c. 1250-1500 (Boston, 2007), 164. For an overview of classical texts that formed part of the school curriculum in Florence, see 121-64.

45. Sacre rappresentazioni composed by the Domenican Friar Antonino Pierozzi were performed by his pupils at the Convent of San Marco as early as 1448 under the patronage of Cosimo de' Medici. See Paola Ventrone, La sacra rappresentazione fiorentina, ovvero la predicazione in forma di teatro (Florence, 2003), 17, and, more recently, Teatro civile e sacra rappresentazione a Firenze nel Rinascimento (Florence, 2016), esp. chaps. 5 and 6. Ventrone, La sacra rappresentazione fiorentina, 5, remarked how the meter of the sacra rappresentazione, the octave, is typical of medieval forms of oral poetry and, as such, "caratterizzato da una forte memorabilità." For rich documentary evidence on the staging of sacre rappresentazioni in Florence in the quattrocento, see the fundamental work of Nerida Newbigin, Nuovo corpus di sacre rappresentazioni fiorentine del Quattrocento: Edite e inedite tratte da manoscritti coevi o ricontrollate su di essi (Bologna, 1983).

46. Black, Education and Society, 164. On Domizi, see Paola Ventrone, "La pedagogia teatrale di Pietro Domizi," in Atti del VII centenario del Duomo di Firenze: La cattedrale e la città; Saggi sul Duomo di Firenze: Atti del Convegno Internazionale di Studi (Firenze, 16-21 giugno 1997), ed. Timothy Verdon and Annalisa Innocenti (Florence, 2001), 1, pt. 2:525-37. An autograph note in BML Ms Plut. 90 sup. 27, fol. 161r, documents the performance of a play of Plautus by the pupils of Luca Bernardi da San Gimignano. 
Poliziano's intellectual interest in ancient drama seems to bloom precisely in this period. De poesi et poetis could then represent the very early stage of his approach to ancient theater. A few years later, probably in 1484-85, Poliziano delivered a course on Terence at the Studio Fiorentino, as documented by the incomplete lecture notes of the already mentioned Andria Terentii. On the occasion of the performance of Plautus's Menaechmi in 1488, Poliziano wrote a prologue at the invitation of Paolo Comparini. ${ }^{47}$ The prologue is stylistically very Plautinian but Terentian in its polemical stance. After customarily exhorting the audience to pay attention to the upcoming performance, Poliziano praises Plautus's Menaechmi for being "witty, humorous and elegant" (lepidam, iocosam, elegantem). Unfortunately, as he remarks, his age must be blamed if secular drama is stigmatized as false (mendosa). Against this accusation, Poliziano argues for the usefulness (utilitas) of ancient drama as an educational tool for the young. At lines 38-46 Poliziano harshly presents the opponents of secular drama who advocate sobriety but live a profligate existence. These malevolent ecclesiastics are depicted with a string of colorful adjectives. They are characterized as "bawling" (clamosi), "fickle" (leves), "hooded" (cucullati), "wearing wooden clogs" (lignipedes), "girded with rope" (cincti funibus), "censorious" (superciliosum), and "sheep with a crooked neck" (incurvicervicum pecus). Mario Martelli identified these detractors as Franciscan preachers active in Florence, specifically Domenico da Ponzo and Bernardino da Feltre. ${ }^{48}$

Da Ponzo and da Feltre, who harshly opposed Lorenzo's cultural program, were winning over popular favor, thanks also to the maneuvers of the anti-Medicean party. Their destabilizing influence put Lorenzo il Magnifico's political authority in danger, and in fact Bernardino da Feltre was exiled in 1488. The staging of Plautus's Menaechmi by Paolo Comparini, who was the canon of the church of San Lorenzo, was a deliberately political move concocted to vindicate Lorenzo's cultural program. $^{49}$

In his extensive discussion of poetics in book 14 of the Genealogy, paraphrased in De poesi et poetis, Boccaccio resolved the debasement of secular poetry by ecclesiastical authorities with the construction of the figure of the poet-theologian, who presents divine truth veiled in the allegorical language of poetry. Poliziano does not embrace the paradigm of the poet-theologian. It seems apparent that

47. Giovanna Bombieri, “Osservazioni sul Prologo ai Menecmi di Angelo Poliziano," in Cardini et al., Tradizione classica e letteratura umanistica, 489-506; Francesco Bausi, "Note sul Prologo ai 'Menecmi' del Poliziano," Interpres 11 (1991): 357-64; and Mario Martelli, "Il prologo di Poliziano ai Menaechmi di Plauto," in Le tradizioni del testo: Studi di letteratura italiana offerti a Domenico de Robertis, ed. Franco Gavazzeni and Guglielmo Gorni (Milan, 1993), 69-83.

48. Mario Martelli, “Il ‘Giacoppo’ di Lorenzo,” Interpres 7 (1987): 103-24.

49. F. W. Kent, Lorenzo de’ Medici and the Art of Magnificence (Baltimore, 2007). 
he aims to solve this conundrum with the aid of ancient sources. In De poesi et poetis the only direct quotation from Plato's dialogues comes from Phaedrus 243a-b. The passage details how Stesichorus was punished with blindness for giving a false mythological account but regained his sight when he retracted the story of Helen in his Palinode. In this passage from Phaedrus, Plato expresses a mitigated judgment on poetry. Poetry can be acceptable insofar as it does not subvert the truth.

At Andria Terentii folio 205r, before setting out to define the subgenres and features of comedy, Poliziano attempts a definition of comedy that I quote in its entirety:

Definitur autem varie et a Graecis quidem nonnullis ita: $\kappa \omega \mu \omega \delta \dot{\alpha} \alpha$ é $\sigma \tau i v$

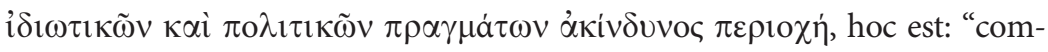
oedia est privatae civilisque fortunae sine periculo vitae comprensio"; ab aliis

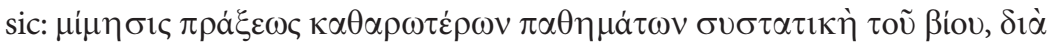

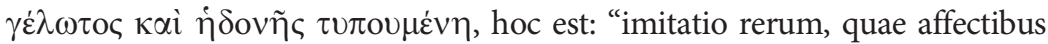
constant mollioribus, representativa vitae, risu et voluptate figurata." Quidam ita descripserunt: "Comoedia est fabula versibus constituta, continens affectum civilium ac privatorum, qua discitur quid sit in vita utile, quid contra evitandum." Cicero comoediam esse ait imitationem vitae, speculum consuetudinis, imaginem veritatis. Livius Andronicus ait comoediam esse cottidianae vitae speculum, nec iniuria. Nam ut intenti speculo veritatis liniamenta facile per imagines colligimus, ita lectione comoediae imitationem vitae consuetudinisque non egerrime animadvertimus. Euantius in commentario Terentii de fabula, hoc est comoedia, sic dicit: "Concinna argumento, consuetudine congrua, utilis sententiis, grata salibus, apta metro.”

[Comedy is defined by drawing on several Greek authors in various ways:

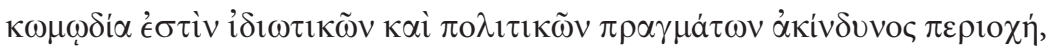
that is "comedy is a treatment of private and public events where there is no risk of life danger" and from others thus $\mu$ í $\eta \sigma \iota \varsigma \pi \rho \dot{\alpha} \xi \varepsilon \omega \varsigma \kappa \alpha \theta \alpha \rho \omega \tau \dot{\varepsilon} \rho \omega \nu$

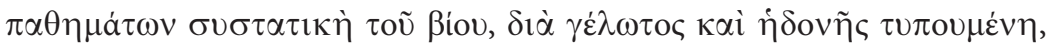
"an imitation of deeds that arise from more tempered passions, representative of life, molded from laughter and pleasure." Some described it like this: "comedy is a fictitious narrative in verse that treats private and civil passions and through which one can learn what in life is useful and what, to the contrary, should be avoided." Cicero says that comedy is an imitation of life, a mirror of custom, an image of truth. Livius Andronicus says that comedy is the mirror of everyday life, and not wrongly. Indeed, just as while intently 
looking at a mirror we can easily make out the features of truth in the reflection, so too without much difficulty we perceive the imitation of life and customs from the example of comedy. Evanthius in his commentary on Terence's play thus defines comedy: "Well-honed in the plot, congruent with customs, useful in its precepts, pleasing in its wit, appropriate in meter."]

In this passage, Poliziano draws heavily on Donatus's treatise On Tragedy and Com$e d y$, which prefaced his commentary on the plays of Terence. Echoing a passage in Donatus that allegedly recalled Cicero, Poliziano describes comedy as "an imitation of life, a mirror of custom, an image of truth" (imitatio vitae, speculum consuetudinis, imago veritatis). ${ }^{50}$ It is precisely in virtue of its ability to mirror real life that comedy can "teach what may be useful in life and what should be avoided" (quid sit in vita utile, quid contra evitandum). Furthermore, comedy, with its characteristically happy ending, is "risk-free" (sine periculo), the passions of its characters are "more tempered" (molliores), and its language is "molded from laughter and pleasure" (risu et voluptate figurata). For these reasons it is less likely to elicit a potentially devastating emotional response in an audience. Poliziano resorts to Donatus to legitimize comedy as a genre that, because it mirrors life in a nonthreatening manner, can become a useful educational tool for the community. This notion, which enjoyed great popularity throughout the fifteenth century and beyond, allows Poliziano to negotiate a balance between Christian and secular authors and find an authoritative voice to silence the opposition of the ecclesiastics to the revival of classical drama.

Poliziano's interest in classical drama is generally ascribed to the mid-1480s at the time when he was preparing his course on Terence at the Studio Fiorentino and composing his prologue to Plautus's Menaechmi. But to fully understand his approach to ancient theater and appreciate his contribution to the development of dramatic criticism, we must consider his painstaking study of ancient theater and its vast commentary tradition as it transpires in the apparently disjointed compilation of his zibaldoni. De poesi et poetis, in particular, attests to his deep understanding of ancient drama and of the intrinsically performative nature of poetry.

50. Donatus, De comoedia et tragoedia, 5.1, in Aeli Donati Commentum Terenti: Accedunt Eugraphi commentum et Scholia Bembina, ed. Paul Wessner (Leipzig, 1902), 1:22. 
APPENDIX

Table A1. Record of BNFC Naz. II.I.99

Description

\begin{tabular}{ll}
\hline Author & Various (see table A2) \\
Date & Circa 1479 (colophon of uncertain reading written by Poliziano in \\
& Greek at fol. 40v) \\
Language & Greek and Latin \\
Script & Humanistic cursive, with marginal notabilia in red ink, semeiosai, and \\
& manicula \\
Scribe & Angelo Poliziano and two other hands (manus A and manus B after \\
& Cesarini Martinelli, "Un ritrovamento polizianesco") \\
Dimensions & $295 \times 225$ (but the first quire is $30 \times 23$ ) \\
Foliation & Folios v+154 \\
Collation & 1 (fols. 1-50), 2-4 and 8 senions, 5 ternion, 6-7 and 11 quaternions, \\
& 9 quinion, 10 binion, 12 quires of seven bifolia \\
Form & Paper codex \\
Binding & Eighteenth century in paper and parchment \\
Attribution & Attributed to Marcello Virgilio Adriani by Carlo Strozzi, who noted \\
& "Marcelli Virgilii" (on the top margin of fol. 141r) and "m. Marcello \\
& Virgilio Adriani" (fol. 154v). Cesarini Martinelli, "Un ritrovamento \\
polizianesco," cogently argued that the manuscript was written by \\
Poliziano and his collaborators.
\end{tabular}

Table A2. De poesi et poetis: A Catalog of Sources

\begin{tabular}{ll}
\hline Folio & Source \\
\hline $1 \mathrm{r}-2 \mathrm{v}$ & $\begin{array}{c}\text { Eusebius-St. Jerome, Chronicon 7-2188 passim. Written by a copyist } \\
\text { (manus A) with autograph notabilia }\end{array}$ \\
Giovanni Boccaccio, Genealogy of the Pagan Gods, bk. 14. Paraphrase of \\
chaps. 7, 9-14, 18-20, and 22. Written by a copyist with autograph \\
notabilia \\
Diogenes Laertius, Lives of Eminent Philosophers, bks. 1-10 passim \\
(partly autograph) \\
Plutarch, Moralia (all autograph): It Is Not Possible to Live Happily \\
Following Epicurus 1087a-f, 1092f-1096c, 1103a-b; Consolation to \\
Apollonius 104a-106c, 109a, 115b; On Exile 602d, 604f, 605c; On the \\
Glory of the Athenians 346f, 347e-348d, 348f, 349a; That a Philoso- \\
pher Ought to Converse Especially with Men in Power 777d, 778c;
\end{tabular}


Table A2 (Continued)

\begin{tabular}{|c|c|}
\hline Folio & Source \\
\hline & $\begin{array}{l}\text { Whether Old Men Should Engage in Public Affairs 785a, 786b, 791e, } \\
\text { 795d; The Dinner of the Seven Wise Men 153e, 156d, 157d, 161a, } \\
\text { 162c-f, 164b; On Isis and Osiris 351d, 353d, 354c, 358f, 364c-d, 365a, } \\
\text { 367c, 369f, 374c-e, 378b; On the Bravery of Women 243a-b, 245c-f, } \\
\text { 248a; On the Eating of Flesh 996c; On Music 1131f, 1132a-f, 1133a, } \\
\text { 1136c, 1141c-d, 1142a, 1144f, 1145d; summary of The Stoics Talk } \\
\text { More Paradoxically than the Poets 1058c; summary of A Comparison } \\
\text { between Aristophanes and Menander (integral text); On the Opinions } \\
\text { of the Philosophers 875e, 879f, 881a, 894b; Greek and Roman Paralle } \\
\text { Stories 306c, 307e, 310f, 312a, 314c; Lives of the Ten Orators 833b-d, } \\
\text { 836c, 837c-d, 839b-f, 841f, 845b; On the E at Delphi 384d, 387b; On } \\
\text { Stoic Self-Contradictions 1033e, 1045a; On the Principles of Cold 948f, } \\
\text { 950e-f; Life of Homer (Pseudo-Plutarch) paraphrased almost entirely, } \\
\text { with the exception of 2.10-70; That We Ought Not to Borrow 830f, } \\
\text { 831f; Consolation to His Wife 608c; On Fate 568d-e }\end{array}$ \\
\hline $26 \mathrm{r}-28 \mathrm{v}$ & $\begin{array}{l}\text { Suidae Lexicon, 808-4115 passim: Athenaeus (731), Acas (808), Acron } \\
\text { (1026), Alexander Aetolus (1127), Alexis Thurius (1138), Alcaeus } \\
\text { (1273-74), Alcimenes (1284), Alcman (1289), alcmanicos eidos } \\
\text { (1290), Alcyonides hemerai (1298), Alphiton (1451), Amyclai (1671), } \\
\text { amphinactizein (1700), Amphion (1751), Amphis (1760), anabionai } \\
\text { (1806), Anagyrasius (1842), Anacreon (1916), Anaxandrides (1982), } \\
\text { Anaxilas (1985), Anaximenes (1989), Anaxippus (1991), Anacharsis } \\
\text { (2130), Antigenides (2657), Antimachus (2681-83), Antiphanes } \\
\text { (2734-35), apage (2762), Apollinarius (3387), Apollodorus (3404- } \\
\text { 7), Apollonius (3419, 3422, 3423), Apollophanes (3409), Araros } \\
\text { (3737), Aratus (3745), Arrianus (3867), Aryballus (3870), Arion } \\
\text { (3886), Aristarchus Theagetes (3893), Aristeas (3900), Aristocles } \\
\text { (3916), Aristomenes (3922), Aristonicus (3924), Aristophanes } \\
\text { (3932), Arisonymus (3936), Aristylus (3938), archadas mimoumenoi } \\
\text { (3946), Arctinus (3960), Archedicus (4082), Archibius (4105), } \\
\text { Archilochus (4112), Archimedes (4113), Archippus (4115) }\end{array}$ \\
\hline $28 v-40 v$ & Pausanias, Description of Greece 9.30.4-11 \\
\hline $40 \mathrm{v}-41 \mathrm{r}$ & List of poets from the Anthology of Planudes \\
\hline $41 \mathrm{r}-\mathrm{v}$ & $\begin{array}{l}\text { Eustathius, Commentaries on Homer's Iliad and Odyssey (excerpts from } \\
\text { the preface and bk. 1) }\end{array}$ \\
\hline $41 \mathrm{v}-42 \mathrm{r}$ & $\begin{array}{l}\text { Biographies of Pindar: Vita metrica and Vita thomana (entirely auto- } \\
\text { graph) }\end{array}$ \\
\hline $42 \mathrm{r}$ & Livy 24.4.2; Apuleius, Florida 7; Plato, Phaedrus 243a-b \\
\hline $42 \mathrm{v}$ & Seneca, Letters to Lucilius $108.8-12$ \\
\hline $43 \mathrm{r}-44 \mathrm{v}$ & Strabo, Geography 1.2.3-10 passim, 1.2 .9 \\
\hline 109r & $\begin{array}{l}\text { Flavius Josephus, Jewish Antiquities 12.2.13; Seneca, Letters to Lucilius } \\
\text { 8.9-10, 9.21; Cicero, On the Orator 1.11 }\end{array}$ \\
\hline
\end{tabular}

All use subject to University of Chicago Press Terms and Conditions (http://www.journals.uchicago.edu/t-and-c). 
Table A2 (Continued)

\begin{tabular}{ll}
\hline Folio & \multicolumn{1}{c}{ Source } \\
\hline $109 \mathrm{v}$ & Quintilian, Institutes of Oratory 1.1.15, 1.1.36; paraphrasis of the life of \\
& Theocritus; Suda, Theocritus, $\theta$ 166; Quintilian, Institutes of Oratory, \\
& $10.1 .55,1.3 .13,1.4 .3-4$ \\
$109 \mathrm{v}-110 \mathrm{v}$ & Cicero, Orator $4,29,35,67-68,109,149,152-53,171,174,178-91$, \\
& $201-2$ \\
$110 \mathrm{v}-111 \mathrm{v}$ & Cicero, On the Ends of Good and Evil 1.4-5, 1.7-9, 1.72, 2.15, 2.24-25, \\
& $2.41,4.56,5.3,5.31-32,5.48-49$ \\
$111 \mathrm{v}$ & Seneca, Letters to Lucilius 49.5 \\
$111 \mathrm{v}-112 \mathrm{r}$ & Tacitus, Dialogue on Oratory 12-13, 5.9, 10.20 \\
$112 \mathrm{r}$ & Aristotle, Politics 1311b \\
\hline
\end{tabular}

